\title{
Effect of four pre-planted cover crop species on weed control and population dynamics
}

\author{
Mohammad Reza Majidi, ${ }^{1}$ Bahram Mirshekari, ${ }^{1}$ Batoul Samedani, ${ }^{2}$ Farhad Farahvash, ${ }^{1}$ \\ Hassan Hajnajari ${ }^{3}$
}

${ }^{1}$ Department of Agronomy and Plant Breeding, Tabriz Branch, Islamic Azad University, Tabriz; ${ }^{2}$ Plant Protection Department, Agricultural Research, Education and Extension Organisation (AREEO), Tehran; ${ }^{3}$ Genetic and Breeding Group, Temperate and Cold Fruits Research Center, Horticulture Sciences Research Institute AREEO, Kataj, Iran

\begin{abstract}
The present research was conducted to assess the competition of four cover crop species including the Festuca ovina L., Festuca rubra L., Agropyron desertorum (Fischer ex Link) Shultes, and Bromus tomentellus Boiss with the weeds as well as enhancement of their establishment. B. tomentellus with 7.7 and $8.73 \mathrm{t} \mathrm{h}^{-1}$ had the highest dry weight production in 2016 and 2017, respectively. In 2016, the highest reduction in the dry weight of the weeds (73\%) was observed for the F. ovina, at the rate of $600 \mathrm{~g}$ active ingredient per ha $\mathrm{a}^{-1}$ of herbicide. In 2017, the highest reduction in the dry weight of the weeds $(90 \%)$ was recorded at the rate of 600 $\mathrm{g}$ active ingredient per ha $\mathrm{a}^{-1}$ of herbicide for the. Dry weight of the dominant weeds decreased by $70 \%$ approximately with the and at the rate of $600 \mathrm{~g}$ active ingredient per ha $\mathrm{ha}^{-1}$ of herbicide. Shannon Wiener index decreased in all the treatments following the increase in the herbicide concentrations in 2016 and 2017. The interaction of cover crop species and herbicide on the Margalef index was significant in all the treatments in 2016 except for $A$. desertorum, as well as $A$. desertorum and in 2017. Margalef index reduced following the increase in the herbicide concentration in all the treatments.
\end{abstract}

Correspondence: Bahram Mirshekari, Department of Agronomy and Plant Breeding, Tabriz Branch, Islamic Azad University, Tabriz, Iran. Tel.: +98.4116372274

E-mail: mirshekari@iaut.ac.ir

Key words: Dry weight; weed control; cover crop; herbicide; population dynamics.

Received for publication: 24 March 2020.

Revision received: 7 July 2020.

Accepted for publication: 7 July 2020.

(C) Copyright: the Author(s), 2020

Licensee PAGEPress, Italy

Italian Journal of Agronomy 2020; 15:1595

doi:10.4081/ija.2020.1595

This article is distributed under the terms of the Creative Commons Attribution Noncommercial License (by-nc 4.0) which permits any noncommercial use, distribution, and reproduction in any medium, provided the original author(s) and source are credited.

\section{Introduction}

Weeds are considered as a hidden foe for crop plants, interfering with their functions and suppressing their growth and development (Jabran et al., 2015a). Resource competition and chemical interference are the interaction mechanisms may occur among plants, simultaneously (Emeterio et al., 2007).

Competition is a negative interaction where individuals make simultaneous demands that exceed limited resources and, while both suffer, one individual suffers less (Booth et al., 2003). Phytochemicals released into the environment inhibit the germination and growth of neighbouring plants by altering their metabolism or influencing their soil community mutualists (Fernandez et al., 2016). Allelochemicals released from allelopathic weeds may disturb the root and shoot growth of emerging crop seedlings (Jabran et al., 2015b). Weed populations in agricultural systems often consist of a broad complex of species and densities making management decisions complicated (Hock et al., 2006). The use of cover plants is regarded as one of the strategies applied for controlling weeds. Cover crops AeroSystems reduce negative environmental effects of ecosystem in agriculture sector, e.g. avoiding ground water nitrate pollution, protecting soils against erosion or improving their fertility (Tribouillois et al., 2015). Cover crop management is a non-specific biological method of pre-emergence weed control (Fourie et al., 2001). The degree weed suppression caused by cover crop depends largely on cover crop species and management systems (Bàrberi and Mazzoncini, 2001). However, many researches have shown that cover crop residue, accompanied with other biologically -based practices, is inadequate alone for constant weed control (Teasdale et al., 2005). Cover crops may provide a source of high quality forage for livestock while reducing the need for herbicide application or tillage (Westbrook et al., 2015). When the cover crop represents perennial plants with the ability to regrow rapidly after cutting, many tall-growing weeds can be restrained satisfactorily by the joint effects of competition and cutting (Håkansson, 2003). Fescues are very diverse grasses which are considered as important components of natural, permanent, and intensively managed grasslands, lawns, turfs used for conservation purposes (Rognli et al., 2010). Red fescue (Festuca rubra) is found on dry to wet sites in open habitats from sea level to high elevations. It grows on sand dunes, dry beaches, and coastal headlands, also on freshwater shores, bogs, and marshes (Mitrović et al., 2008). The latter species is also tolerant to shade and other stress factors, which makes it a highly competitive plant (Sikoriya, 2014). Bromusis, an important perennial grass species belonging to genus of Bromus, subgenus of Festucoides and family of Poaceae grows naturally in Zagros and Alborz mountain rangelands in the west and north of 
Iran. Bromus tomentellus characterised by early growth in spring and good foraging quality has also good adaptability in severe ambiental conditions (Armaki et al., 2013). A desertorum Schult is a cool season grass belonging to Poaceae family, possessing good adaptability in the arid climates (Goraghani et al., 2013). The present experiment was aimed to investigate the competition between four species of cover crop with the weeds as well as the improvement of their establishment in Karaj province, Iran.

\section{Materials and methods}

\section{Experimental site}

This study was conducted in split plots as a randomised complete block design (RCBD) with three replications, in October 2015 to June 2017. The experimental apple orchard with 7 and 8year-old trees of cultivars Gala and Granny Smith was established in Meshkin Abad Hort. Research Station located in Karaj-Iran.

The city is located at $51^{\circ}$ east longitude and $35^{\circ}, 48$ min north latitude, a height of 1297 s.l.m. semi-dry climate, average annual rainfall and temperature $280 \mathrm{~mm}$ and is $14^{\circ} \mathrm{C}$ and relative humidity is $53 \%$. The minimum and maximum average temperatures are 8 and $20.8^{\circ} \mathrm{C}$, respectively.

\section{Field layout and treatments details}

The main factor of cover crop species included 5 levels: Festuca ovina, Festuca rubra, Agropyron desertorum, Bromus tomentellus, and control (no cover crop and weed control), and the sub-factor included 4 levels of $0,300,450$ and $600 \mathrm{~g}$ a.i. ha ${ }^{-1}$ consisting of broad-leaf herbicide Bromocide M.A. EC. Recommended dose, of this herbicide for control of broadleaf weeds is $600 \mathrm{~g}$ a.i. $\mathrm{ha}^{-1}$. According to the prevalence of broad-leaf weeds in the studied field, broad-leaf herbicide Bromocide M.A. EC was used based on the findings of the previous studies to facilitate the establishment of cover crops against weeds (Hein, 2014; Reddy, 2003). Herbicide spraying was performed using a sprayer equipped with a 2.5 bar pressure nozzle in late March. The dimensions of each plot were equal to $3.5 \times 3.5 \mathrm{~m}$. Before planting cover crops, the ground was rotated to remove the remains of the plants on the soil and the ground was graded. After rolling, seeds of the cover crops were planted in early October. Planting density for $F$. ovina and $F$. rubra cover crops was equal to $30 \mathrm{~kg} \mathrm{ha}^{-1}$ and $60 \mathrm{~kg}$ $\mathrm{ha}^{-1}$ for $A$. desertorum and $B$. tomentellus, respectively. Planting density for $F$. ovina and $F$. rubra cover crops was equal to $30 \mathrm{~kg}$ $\mathrm{ha}^{-1}$ and $60 \mathrm{~kg} \mathrm{ha}^{-1}$ for $A$. desertorum and B. tomentellus, respectively. The cover crops were irrigated three times before their emergence in the form of flooding. Water flow rate for irrigation was $14 \mathrm{~m}^{3} \mathrm{ha}^{-1}$. The mineral fertilisers urea, diammonium phosphate (DAP) and potassium sulphate were used as sources of nitrogen, phosphorus and potassium, respectively. All of the N, P and K were distributed and incorporated thoroughly into the soil at a rate of $100 \mathrm{~kg} \mathrm{ha}^{-1}$ based on the soil test (Table 1) at sowing. while planting cover crop. Soil texture was in the test site clay loam. The weed and cover crops were monitored twice a year, once in the middle of May prior to spraying by herbicide and then in early June after spraying by herbicide including counting weeds according to the species using $0.5 \times 0.5 \mathrm{~m}^{2}$ quadrates in each sub-plot. The weed dry weight was also measured individually. The weed and cover crop dry weights were measured after $48 \mathrm{~h}$ in oven at $70^{\circ} \mathrm{C}$.

\section{Ecological indicators}

In order to evaluate the effect of cover crops on weed diversity, Shannon Wiener Index ( $\left.\mathrm{H}^{\prime}\right)$ (Equation 1) was used, and Margalof index (Equation 2) was used in order to determine the species richness.

$\mathrm{H}^{\prime}=-\sum \mathrm{pi} \times \log \mathrm{pi}$

Where:

$\mathrm{pi}=\mathrm{Ni} / \mathrm{N}$,

$\mathrm{pi}=$ relative frequency of species,

$\mathrm{Ni}=$ the number of individuals of species $\mathrm{i}$,

$\mathrm{N}=$ total number of individuals recorded in the sample to be rarefied;

$\mathrm{M}=(\mathrm{S}-1) / \operatorname{lnN}$

Where:

$\mathrm{S}=$ the number of species,

$\mathrm{N}=$ the total number of individuals.

\section{Statistical analysis}

For data analysis, the data was normalised first, and after ensuring the normality of the data, the data were analysed by SAS software. The mean comparison was done by Tukey's test at $5 \%$ of significance level. The cut off of interactive effect was performed, when the interactive effect was measured.

\section{Results}

\section{Dry weight of cover crop (before application of herbicide)}

In 2016 and 2017, B. tomentellus with 7.7 and 8.73 tons per hectare, respectively had the highest biomass production compared to three species. A. desertorum biomass was equal to 3.9 tons per hectare in the first year and 4.03 tons per hectare in the second year and was found to be less in both years than the other three species (Table 2). In 2016 and 2017, F. ovina with 4.8 and 6.8 tons per hectare and $F$. rubra with 4.7 and 6.03 tonh $^{-1}$, respectively were placed after $B$. tomentellus treatment (Table 2). Generally, the changes in the dry weight produced among the species of cover crops were identical for each year of experiment. In this study, the production of dry weight of cover crops was higher in the second year than the first year, but this increase was not the same for all four cover crops.

Table 1. Soil properties of experiment site.

\begin{tabular}{|c|c|c|c|c|c|c|c|c|}
\hline Soil texture & $\begin{array}{c}\text { P } \\
\text { mg /ha }\end{array}$ & $\frac{\mathrm{K}}{\mathrm{mg} / \mathrm{ha}}$ & $\begin{array}{l}\text { Clay } \\
(\%)\end{array}$ & $\begin{array}{l}\text { Sand } \\
(\%)\end{array}$ & $\begin{array}{l}\mathrm{Ph} \\
(\%)\end{array}$ & $\begin{array}{l}\text { Silt } \\
(\%)\end{array}$ & $\begin{array}{l}\text { OC } \\
(\%)\end{array}$ & $\mathbf{N}$ \\
\hline Clay-loam & 17 & 367 & 34 & 40 & 7.5 & 26 & 0.78 & 0.12 \\
\hline
\end{tabular}




\section{Dry weight of cover crop (after application of herbicide)}

The interaction between cover crop and different levels of herbicide was not significant for dry biomass of cover crops. In the second harvest in 2016 and 2017, the highest dry biomass production (8.6 and 9.7 tons per hectare, respectively) was reported for B. tomentellus. In 2016 and 2017, the lowest dry biomass of cover crops (3.4 and 4.1) tons per hectare, respectively) was observed for A. desertorum treatment.

\section{Total weeds density and dry weight (before application of herbicide)}

A. desertorum treatment with 22.6 and 11.6 weed per square meter had the highest total weed density after the control treatment with 24 and 15.6 weed plant $\mathrm{m}^{-2}$ in 2016 and 2017, respectively (Table 3). In the 2016 crop year, the highest reduction in the total density of broad-leaf weed was observed for B. tomentellus, $F$. ovina and F. rubra treatments, obtained by $54 \%, 51.6 \%$ and $8 \%$, respectively, and in 2016, it was obtained by $64 \%, 44 \%$ and $29 \%$, respectively compared to the control treatment. In the second year of the experiment, due to the greater production of dry biomass of cover crops, the emergence of weeds was further stopped (Table 3 ). The lowest dry weight of total weeds was observed for $B$. tomentellus treatment, obtained by 5.5 and $3.3 \mathrm{gm}^{-2}$ compared to the control treatment, and it was also obtained by 12.4 and 15.5 $\mathrm{gm}^{-2}$, respectively in 2016 and 2017 (Table 4), which is probably due to the production of more biomass by. The highest dry weight of broad-leaf weeds among cover crops was observed in $A$. desertorum treatment, obtained by $10.5 \mathrm{gm}^{-2}$ for the first year and 9.4 $\mathrm{gm}^{-2}$ for the second year. B. tomentellus treatment had $55 \%$ and $78 \%$, treatment had $41 \%$ and $71 \%$, and F. rubra treatment had $32 \%$ and $61 \%$ of dry weight of total weeds compared to control in 2016 and 2017 , respectively.

The reduction in dry weight of total broad-leaf weeds influenced by $B$. tomentellus in both years of the experiment was found to be more than other cover crops, and it is mainly associated with its high production of dry biomass caused the prevention of weed emergence in the first year by covering more soil surface and also in the second year, prevented weed growth in the growing season through pressure and competition.

\section{Total density and dry weight of weeds (after application of herbicide)}

In 2016, the interaction between cover crop and herbicide levels was significant on total weed density in all treatments other than $F$. ovina and in 2016, it was found to be significant on all treatments. In 2016, the lowest and highest reduction in total weed density at $600 \mathrm{~g}$ a.i. ha ${ }^{-1}$ concentration of used herbicide in B. tomentellus and $A$. desertorum was equal to $35 \%$ and $45 \%$, respectively. In 2016 , with a reversal trend compared to 2016, the highest and lowest reduction in total broad-leaf weed density at concentration of $600 \mathrm{~g}$ a.i. ha $\mathrm{h}^{-1}$ was observed in $B$. tomentellus and $A$. desertorum treatments, obtained by $79 \%$ and $36 \%$, respectively. In each two years of experiment, no significant difference was found in terms of total weed density between 600 and $450 \mathrm{~g}$ a.i. $\mathrm{ha}^{-1}$ concentrations among the control treatments (Table 5). In 2016, the interaction between cover crop and herbicide concentration was significant on dry weight of total weeds except for B. tomentellus and in 2016; it was found to be significant on all treatments. In 2016, the highest and lowest reduction in dry weight of broad-leaf weeds at the concentration of $600 \mathrm{~g}$ a.i. ha ${ }^{-1}$ was observed in F. ovina and A. desertorum treatments, obtained by $94 \%$ and $59 \%$, respectively compared to control (Table 5), and in the same year, no statistically significant difference was found between levels of 600 and $450 \mathrm{~g}$ a.i. ha ${ }^{-1}$ of herbicide in control treatment. For the treatment of $F$. ovina at concentrations of 450 and $300 \mathrm{~g}$ a.i. ha ${ }^{-1} 68 \%$ and $44 \%$ reduction was observed in weed dry weight, respectively. In 2016 , reduction of weed dry weight was influenced by the interaction between cover crop and herbicide concentrations in B. tomentellus, $F$. ovina, A. desertorum and F. rubra treatments, obtained by $90 \%$, $73.66 \%$ and $56 \%$ at the concentration of $600 \mathrm{~g}$ a.i. ha ${ }^{-1}$, and at concentrations of 450 and $300 \mathrm{~g}$ a.i. ha ${ }^{-1}$, the highest reduction of total weed dry weight was observed in F. rubra treatment, obtained by $29 \%$. In the second year, a lower reduction was observed in weed dry

Table 2. Mean comparison of dry weight of cover crop in 2016 and 2017.

\begin{tabular}{cccc} 
Year & Cover crop dry weight ton/ha & F. ovina \\
& A. desentorum & B. tomentellus & $4.82^{\mathrm{b}}$ \\
2016 & $3.96^{\mathrm{c}}$ & $4.77^{\mathrm{b}}$ & $7.56^{\mathrm{a}}$ \\
2017 & $4.03^{\mathrm{c}}$ & $6.03^{\mathrm{b}}$ & $6.81^{\mathrm{b}}$ \\
\hline
\end{tabular}

Means within columns followed by the same letter are not significantly different at $5 \%$ probability level in Tukey HSD test.

Table 3. Mean comparison of total weeds density (plant $\mathbf{m}^{-2}$ ) under cover crop in 2016 and 2017 before application of herbicide.

\begin{tabular}{|c|c|c|c|c|c|}
\hline \multirow[t]{2}{*}{ Year } & \multicolumn{5}{|c|}{ Cover crop dry weight ton/ha } \\
\hline & A. desertorum & B. tomentellus & F. ovina & F. rubra & Control \\
\hline 2016 & $22.66^{\mathrm{a}}$ & $11^{b}$ & $11.66^{\mathrm{b}}$ & $22^{\mathrm{a}}$ & $24^{\mathrm{a}}$ \\
\hline 2017 & $11.66^{\mathrm{b}}$ & $5.66^{\mathrm{d}}$ & $8.66^{\mathrm{c}}$ & $11^{\mathrm{bc}}$ & $15.66^{\mathrm{a}}$ \\
\hline
\end{tabular}

Means within columns followed by the same letter are not significantly different at 5\% probability level in Tukey HSD test.

Table 4. Mean comparison of total weeds dry weight $\left(\mathrm{gm}^{2}\right)$ under cover crop in 2016 and 2017 before application of herbicide.

\begin{tabular}{|c|c|c|c|c|c|}
\hline \multirow[t]{2}{*}{ Year } & \multicolumn{5}{|c|}{ Cover crop dry weight ton/ha } \\
\hline & A. desertorum & B. tomentellus & F. ovina & F. rubra & Control \\
\hline 2016 & $10.53^{c}$ & $5.56^{\text {gh }}$ & $7.26^{\mathrm{ef}}$ & $8.4^{\mathrm{de}}$ & $12.4^{\mathrm{b}}$ \\
\hline 2017 & $9.4 g^{c d}$ & $3.36^{\mathrm{i}}$ & $4.4 \mathrm{~h}^{\mathrm{i}}$ & $6.03^{\mathrm{gh}}$ & $15.5^{\mathrm{a}}$ \\
\hline
\end{tabular}

Means within columns followed by the same letter are not significantly different at 5\% probability level in Tukey HSD test. 
weight than the first year (Table 5). This was due to the reduction in weed density caused by the presence of cover crops and interaction with herbicide in the first year of the experiment.

\section{Total density and dry weight of dominant weeds of the field}

In both years of experiment, the dominant weeds were Polygonum aviculare L, Alyssum desertorum Stapf and
Descurainia Sophia (L.) Webb ex Prantl In both years. In both years of experiment, the interactive effect between herbicide concentration and cover crop on total dominant weed density was found to be significant on all treatments other than $F$. ovina and $B$. tomentellus. In both years, for the control treatment, the concentration of $450 \mathrm{~g}$ a.i. ha ${ }^{-1}$ showed no statistically significant difference with $300 \mathrm{~g}$ a.i. $\mathrm{ha}^{-1}$ concentration (Table 6). Also, by increasing the concentration of herbicide, the total density of weeds reduced in

Table 5. The interaction between cover crop and herbicide concentration in 2016 and 2017 for total density and dry weight of weeds.

\begin{tabular}{|c|c|c|c|c|}
\hline \multirow[t]{2}{*}{ Cover crop xherbicide (g a.i/ha) } & \multicolumn{2}{|c|}{2016} & \multicolumn{2}{|c|}{2017} \\
\hline & $\begin{array}{c}\text { Density } \\
\text { (plants/m²) }\end{array}$ & $\begin{array}{l}\text { Dry weight } \\
\left(\mathrm{gm}^{2}\right)\end{array}$ & $\begin{array}{c}\text { Density } \\
\text { (plants/m²) }\end{array}$ & $\begin{array}{l}\text { Dry weight } \\
\left(\mathrm{gm}^{2}\right)\end{array}$ \\
\hline A. desertorum $\times 0$ & $18^{a}$ & $15.2^{\mathrm{a}}$ & $13^{\mathrm{a}}$ & $13.6^{\mathrm{a}}$ \\
\hline A. desertorum $\times 300$ & $15^{b}$ & $10.7^{\mathrm{ab}}$ & $10.3^{b}$ & $12.8^{\mathrm{a}}$ \\
\hline A. desertorum $\times 450$ & $11.3^{c}$ & $7.5^{\mathrm{b}}$ & $8.6^{\mathrm{bc}}$ & $6^{b}$ \\
\hline A. desertorum $\times 600$ & $9.6^{\mathrm{c}}$ & $6.2^{\mathrm{b}}$ & $8.3^{\mathrm{c}}$ & $4.5^{\mathrm{b}}$ \\
\hline B. tomentellus $\times 0$ & $9.3^{\mathrm{a}}$ & $7.3^{\mathrm{a}}$ & $6.3^{\mathrm{a}}$ & $2^{\mathrm{a}}$ \\
\hline B. tomentellus $\times 300$ & $8^{a b}$ & $5.9^{\mathrm{a}}$ & $5^{\mathrm{ab}}$ & $1.8^{\mathrm{a}}$ \\
\hline B. tomentellus $\times 450$ & $7^{\mathrm{bc}}$ & $2.4^{\mathrm{a}}$ & $4^{b}$ & $1.2^{\mathrm{a}}$ \\
\hline B. tomentellus $\times 600$ & $6^{c}$ & $1.6^{\mathrm{a}}$ & $1.3^{\mathrm{c}}$ & $.2^{\mathrm{b}}$ \\
\hline F. ovina $\times 0$ & $12.6^{\mathrm{a}}$ & $10.1^{\mathrm{a}}$ & $10^{\mathrm{a}}$ & $3.04^{\mathrm{a}}$ \\
\hline F. ovina $\times 300$ & $12.3^{\mathrm{a}}$ & $5.6^{\mathrm{ab}}$ & $8.3^{b}$ & $2.7^{\mathrm{b}}$ \\
\hline F. ovina $\times 450$ & $10^{\mathrm{a}}$ & $3.2^{\mathrm{b}}$ & $5.6^{\mathrm{c}}$ & $2.08^{c}$ \\
\hline F. ovina $\times 600$ & $8.6^{\mathrm{a}}$ & $0.6^{c}$ & $3^{\mathrm{d}}$ & $0.8^{\mathrm{d}}$ \\
\hline F. rubra $\times 0$ & $15.3^{\mathrm{a}}$ & $10.5^{\mathrm{a}}$ & $10^{\mathrm{a}}$ & $8.03^{\mathrm{a}}$ \\
\hline F. rubra $\times 300$ & $13^{\mathrm{b}}$ & $6.8^{\mathrm{b}}$ & $9.6^{\mathrm{a}}$ & $5.7^{\mathrm{ab}}$ \\
\hline F. rubra $\times 450$ & $12^{\mathrm{c}}$ & $5.6^{\mathrm{bc}}$ & $7^{\mathrm{b}}$ & $5^{b}$ \\
\hline F. rubra $\times 600$ & $9^{d}$ & $4.8^{c}$ & $5.3^{b}$ & $3.5^{\mathrm{b}}$ \\
\hline Control $\times 0$ & $35.6^{\mathrm{a}}$ & $5.9 \mathrm{ac}$ & $20.6^{\mathrm{a}}$ & $27.3^{\mathrm{a}}$ \\
\hline Control $\times 300$ & $28.3^{\mathrm{a}}$ & $4.3^{\mathrm{ab}}$ & $18.6^{\mathrm{a}}$ & $23.9^{\mathrm{a}}$ \\
\hline Control $\times 450$ & $16.3^{\mathrm{b}}$ & $3.2^{\mathrm{bc}}$ & $13^{b}$ & $13.2^{\mathrm{b}}$ \\
\hline Control $\times 600$ & $16.6^{\mathrm{b}}$ & $1.6^{c}$ & $11^{\mathrm{b}}$ & $5.9^{c}$ \\
\hline
\end{tabular}

Means within columns followed by the same letter are not significantly different at $5 \%$ probability level in Tukey HSD test.

Table 6. The interactive effect between herbicide concentration and cover crop on total dominant weed density and dry weight in 2016 and 2017.

\begin{tabular}{|c|c|c|c|c|}
\hline Cover crop xherbicide (g a.i/ha) & & & & \\
\hline & $\begin{array}{c}\text { Density } \\
\text { (plants/m²) }\end{array}$ & $\begin{array}{l}\text { Dry weight } \\
\left(\mathrm{gm}^{2}\right)\end{array}$ & $\begin{array}{c}\text { Density } \\
\text { (plants/m²) }\end{array}$ & $\begin{array}{l}\text { Dry weight } \\
\left(\mathrm{gm}^{2}\right)\end{array}$ \\
\hline A. desertorum $\times 0$ & $8^{a}$ & $4.1^{\mathrm{a}}$ & $7^{\mathrm{a}}$ & $3.7^{\mathrm{a}}$ \\
\hline A. desertorum $\times 300$ & $5.6^{\mathrm{ab}}$ & $3.7^{\mathrm{a}}$ & $5.6^{\mathrm{ab}}$ & $2.9^{\mathrm{ab}}$ \\
\hline A. desertorum $\times 450$ & $4^{\mathrm{bc}}$ & $2.05^{b}$ & $3.6^{\mathrm{bc}}$ & $2.05^{\mathrm{bc}}$ \\
\hline A. desertorum $\times 600$ & $3.2^{\mathrm{bc}}$ & $1.9^{b}$ & $3^{c}$ & $1.4^{\mathrm{c}}$ \\
\hline B. tomentellus $\times 0$ & $3^{\mathrm{a}}$ & $2.2^{\mathrm{a}}$ & $3.3^{\mathrm{a}}$ & $1.9^{\mathrm{a}}$ \\
\hline B. tomentellus $\times 300$ & $3^{\mathrm{a}}$ & $1.6^{\mathrm{ab}}$ & $3^{a}$ & $0.99^{\mathrm{b}}$ \\
\hline B. tomentellus $\times 450$ & $3^{\mathrm{a}}$ & $0.5^{b c}$ & $3^{\mathrm{a}}$ & $0.51^{\mathrm{b}}$ \\
\hline B. tomentellus $\times 600$ & $3^{\mathrm{a}}$ & $0.33^{c}$ & $3^{a}$ & $0.51^{\mathrm{b}}$ \\
\hline F. ovina $\times 0$ & $3^{\mathrm{a}}$ & $4.1^{\mathrm{a}}$ & $3.3^{\mathrm{a}}$ & $2.4^{\mathrm{a}}$ \\
\hline F. ovina $\times 300$ & $3^{\mathrm{a}}$ & $2.04^{\mathrm{b}}$ & $3.3^{\mathrm{a}}$ & $1.6^{\mathrm{a}}$ \\
\hline F. ovina $\times 450$ & $3^{\mathrm{a}}$ & $1.2^{\mathrm{c}}$ & $3^{\mathrm{a}}$ & $0.56^{\mathrm{b}}$ \\
\hline F. ovina $\times 600$ & $3^{\mathrm{a}}$ & $0.95^{\mathrm{c}}$ & $3^{\mathrm{a}}$ & $0.48^{b}$ \\
\hline F. rubra $\times 0$ & $7.6^{\mathrm{a}}$ & $3.5^{\mathrm{a}}$ & $6^{\mathrm{a}}$ & $2.2^{\mathrm{a}}$ \\
\hline F. rubra $\times 300$ & $4.6^{\mathrm{b}}$ & $2.9^{\mathrm{a}}$ & $5^{\mathrm{a}}$ & $2.1^{\mathrm{ab}}$ \\
\hline F. rubra $\times 450$ & $3.3^{\mathrm{b}}$ & $1.8^{b}$ & $3.3^{\mathrm{b}}$ & $1.5^{\mathrm{bc}}$ \\
\hline F. rubra $\times 600$ & $3^{b}$ & $1.07^{\mathrm{b}}$ & $3^{b}$ & $1.2^{\mathrm{c}}$ \\
\hline Control $\times 0$ & $7.3^{\mathrm{a}}$ & $5.9^{\mathrm{a}}$ & $7^{\mathrm{a}}$ & $7.8^{\mathrm{a}}$ \\
\hline Control $\times 300$ & $5.3^{\mathrm{b}}$ & $4.3^{a b}$ & $6.6^{\mathrm{a}}$ & $5.5^{\mathrm{b}}$ \\
\hline Control $\times 450$ & $5.3^{\mathrm{b}}$ & $3.2^{\mathrm{bc}}$ & $6.3^{\mathrm{a}}$ & $1.6^{\mathrm{c}}$ \\
\hline Control $\times 600$ & $3^{c}$ & $1.6^{\mathrm{c}}$ & $3.6^{\mathrm{b}}$ & $0.65^{\mathrm{d}}$ \\
\hline
\end{tabular}

Means within columns followed by the same letter are not significantly different at $5 \%$ probability level in Tukey HSD test. 
both years. In 2016, the highest reduction in total weed density, caused by the interactions between the two treatments of $A$. desertorum and F. rubra was observed at $600 \mathrm{~g}$ a.i. ha ${ }^{-1}$ concentration, obtained by $60 \%$ and $60 \%$, respectively compared to control, and it was not statistically significant at concentrations of 450 and 600 g a.i. ha ${ }^{-1}$, respectively.

In 2016, the highest reduction in total weed density was found to be by $57 \%$, influenced by the interactive effect of $A$. desertorum treatment at $600 \mathrm{~g}$ a.i. $\mathrm{ha}^{-1}$ concentration compared to the control, which was not significantly different with $450 \mathrm{~g}$ a.i. ha ${ }^{-1}$ concentration (Table 6). The lowest reduction was observed in F. rubra treatment, obtained by $28.5 \%$.

The interactive effect of herbicide concentration and cover crop on total weed weights was found to be significant in all treatments in both years of experiment. In 2016, the highest reduction in dry weight of total dominant weeds was observed to be influenced by $B$. tomentellus treatment at 450 and $600 \mathrm{~g}$ a.i. ha ${ }^{-1}$ concentrations ( $77 \%$ and $85 \%$, respectively) and for $F$. ovina, it was obtained by $76 \%$ and $70 \%$, respectively (Table 6 ), compared to the control treatment. In the second year of experiment, the highest reduction in dry weight of dominant weeds was observed to be influenced by the interaction between cover crop and herbicide in F. ovina treatment at 450 and $600 \mathrm{~g}$ a.i. ha ${ }^{-1}$ concentrations, respectively, obtained by $80 \%$ and $76 \%$, respectively, and then for treatment $B$. tomentellus, it was obtained by $73 \%$ and $73 \%$ at 600 and $450 \mathrm{~g}$ a.i. $\mathrm{ha}^{-1}$ concentrations, respectively. For two treatments of $F$. ovina and $B$. tomentellus, the total dry weight reduction of the dominant weeds was not significantly influenced by the interaction between the cover crop and the herbicide concentration for concentrations of 450 and $600 \mathrm{~g}$ a.i. ha ${ }^{-1}$ of effective ingredient, which is due to the reduction in weed density, thus the interactive effect on dry weight of weeds was not significant (Table 6).

The interactive effect between herbicide concentration and cover crop on density and dry weight of three dominant weeds.
In 2016 and 2017, the interaction between cover crop and different levels of herbicide on dry weight of $D$. Sophia was found to be significant in all treatments except for $B$. tomentellus and $F$. rubra. In 2016 and 2016, the highest reduction in dry weight of $D$. Sophia was observed in treatment, obtained by $84 \%$ and $80 \%$, respectively, and at a concentration of $600 \mathrm{~g}$ a.i. ha ${ }^{-1}$ (Table 7).

In 2016, the interaction between cover crop and herbicide levels on dry weight of $A$. desertorum was not significant in other treatments except for the control treatment, and in 2017 it was not found to be statistically significant in two treatments of $B$. tomentellus and $F$. ovina. The two treatments were able to reduce $79 \%$ and $84 \%$ of dry weight of $A$. desertorum compared to the control treatment at the concentration of $600 \mathrm{~g}$ a.i. ha ${ }^{-1}$. In 2016, the interaction between cover crop and herbicide levels on $P$. aviculare was significant in both and $F$. ovina treatments and in 2017 , it was found to be significant in all treatments. For two treatments of $B$. tomentellus and, $79 \%$ and $63 \%$ of $P$. aviculare reduced, respectively. In 2017, the highest reduction in this weed was observed for $F$. ovina treatment, obtained by $84 \%$. Seemingly, due to more weed density in the control treatment, no higher reduction was observed in dry weight of dominant weeds (Table 7).

\section{Ecological indicators}

After identification and based on the photosynthetic genotype, the main broadleaf weeds in the field were listed in Table 8. The weeds recorded in two years of experiment included dicotyledon and they were mostly one year old.

\section{Diversity index}

In 2016 and 2017, based on Shannon Wiener $\left(H^{\prime}\right)$ index, the interaction between cover crop and herbicide concentration of Bromocide M.A.EC was significant in all treatments (Table 9). By increasing the concentration of herbicide, the index reduced in all treatments. The highest percentage of reduction influenced by the

Table 7. The interactive effect between herbicide concentration and cover crop on density and dry weight of three dominant weeds in 2016 and 2017.

\begin{tabular}{|c|c|c|c|c|c|c|}
\hline Cover crop xherbicide (g a.i/ ha) & P. aviculare & $\begin{array}{l}2016 \\
\text { Ory weight (gm²) } \\
\text { A. desertorum }\end{array}$ & D. Sophia & P. aviculare & $\begin{array}{l}2017 \\
\text { Ory weight (gm² } \\
\text { A. desertorum }\end{array}$ & D. Sophia \\
\hline $\begin{array}{l}\text { A. } \text { desertorum } \times 0 \\
\text { A. desertorum } \times 300 \\
\text { A. desertorum } \times 450 \\
\text { A. desertorum } \times 600\end{array}$ & $\begin{array}{c}0.83^{\mathrm{a}} \\
0.75^{\mathrm{a}} \\
0.53^{\mathrm{a}} \\
0.4^{\mathrm{a}}\end{array}$ & $\begin{array}{l}1.5^{\mathrm{a}} \\
1.2^{\mathrm{a}} \\
0.65^{\mathrm{a}} \\
0.43^{\mathrm{a}}\end{array}$ & $\begin{array}{c}1.7^{\mathrm{a}} \\
1.6^{\mathrm{ab}} \\
1.06^{\mathrm{ab}} \\
0.87^{\mathrm{b}}\end{array}$ & $\begin{array}{c}0.77^{\mathrm{a}} \\
0.75^{\mathrm{a}} \\
0.58^{\mathrm{ab}} \\
0.39^{\mathrm{b}}\end{array}$ & $\begin{array}{l}1.3^{\mathrm{a}} \\
0.95^{\mathrm{a}} \\
0.77^{\mathrm{a}} \\
0.43^{\mathrm{a}}\end{array}$ & $\begin{array}{l}1.6^{\mathrm{a}} \\
1.25^{\mathrm{a}} \\
0.69^{\mathrm{b}} \\
0.63^{\mathrm{b}}\end{array}$ \\
\hline $\begin{array}{l}\text { B. tomentellus } \times 0 \\
\text { B. tomentellus } \times 300 \\
\text { B. tomentellus } \times 450 \\
\text { B. tomentellus } \times 600\end{array}$ & $\begin{array}{c}0.43^{\mathrm{a}} \\
0.37^{\mathrm{ab}} \\
0.2^{\mathrm{ab}} \\
0.1^{\mathrm{b}}\end{array}$ & $\begin{array}{l}0.66^{\mathrm{a}} \\
0.65^{\mathrm{a}} \\
0.21^{\mathrm{a}} \\
0.10^{\mathrm{a}}\end{array}$ & $\begin{array}{c}1.1^{\mathrm{a}} \\
0.56^{\mathrm{a}} \\
0.137^{\mathrm{a}} \\
0.127^{\mathrm{a}}\end{array}$ & $\begin{array}{l}0.43^{\mathrm{a}} \\
0.34^{\mathrm{ab}} \\
0.15^{\mathrm{b}} \\
0.11^{\mathrm{b}}\end{array}$ & $\begin{array}{l}0.58^{\mathrm{a}} \\
0.23^{\mathrm{b}} \\
0.16^{\mathrm{b}} \\
0.12^{\mathrm{b}}\end{array}$ & $\begin{array}{l}0.90^{\mathrm{a}} \\
0.40^{\mathrm{ab}} \\
0.23^{\mathrm{b}} \\
0.22^{\mathrm{b}}\end{array}$ \\
\hline $\begin{array}{l}\text { F. ovina } \times 0 \\
\text { F. ovina } \times 300 \\
\text { F. ovina } \times 450 \\
\text { F. ovina } \times 600\end{array}$ & $\begin{array}{l}0.80^{\mathrm{a}} \\
0.66^{\mathrm{a}} \\
0.34^{\mathrm{b}} \\
0.29^{\mathrm{b}}\end{array}$ & $\begin{array}{l}1.1^{\mathrm{a}} \\
0.47^{\mathrm{a}} \\
0.39^{\mathrm{a}} \\
0.33^{\mathrm{a}}\end{array}$ & $\begin{array}{l}2.1^{\mathrm{a}} \\
0.9^{\mathrm{b}} \\
0.53^{\mathrm{b}} \\
0.32^{\mathrm{b}}\end{array}$ & $\begin{array}{c}0.77^{\mathrm{a}} \\
0.48^{\mathrm{b}} \\
0.26^{\mathrm{bc}} \\
0.12^{\mathrm{c}}\end{array}$ & $\begin{array}{l}0.83^{\mathrm{a}} \\
0.42^{\mathrm{ab}} \\
0.28^{\mathrm{b}} \\
0.13^{\mathrm{b}}\end{array}$ & $\begin{array}{l}1.08^{\mathrm{a}} \\
0.79^{\mathrm{a}} \\
0.28^{\mathrm{b}} \\
0.21^{\mathrm{b}}\end{array}$ \\
\hline $\begin{array}{l}\text { F. rubra } \times 0 \\
\text { F. rubra } \times 300 \\
\text { F. rubra } \times 450 \\
\text { F. rubra } \times 600\end{array}$ & $\begin{array}{l}1.9^{\mathrm{a}} \\
1.3^{\mathrm{a}} \\
1.1^{\mathrm{a}} \\
0.6^{\mathrm{a}}\end{array}$ & $\begin{array}{l}1.9^{\mathrm{a}} \\
1.3^{\mathrm{a}} \\
1.1^{\mathrm{a}} \\
0.67^{\mathrm{a}}\end{array}$ & $\begin{array}{l}1.9^{\mathrm{a}} \\
1.3^{\mathrm{ab}} \\
1.2^{\mathrm{ab}} \\
0.72^{\mathrm{b}}\end{array}$ & $\begin{array}{c}0.61^{\mathrm{a}} \\
0.54^{\mathrm{ab}} \\
0.40^{\mathrm{ab}} \\
0.29^{\mathrm{b}}\end{array}$ & $\begin{array}{l}0.60^{\mathrm{a}} \\
0.53^{\mathrm{a}} \\
0.46^{\mathrm{a}} \\
0.38^{\mathrm{a}}\end{array}$ & $\begin{array}{l}1.1^{\mathrm{a}} \\
0.98^{\mathrm{a}} \\
0.58^{\mathrm{a}} \\
0.49^{\mathrm{a}}\end{array}$ \\
\hline $\begin{array}{l}\text { Control } \times 0 \\
\text { Control } \times 300 \\
\text { Control } \times 450 \\
\text { Control } \times 600\end{array}$ & $\begin{array}{l}1.7^{\mathrm{a}} \\
1.5^{\mathrm{ab}} \\
0.44^{\mathrm{b}} \\
0.33^{\mathrm{b}}\end{array}$ & $\begin{array}{c}1.5^{\mathrm{a}} \\
1.4^{\mathrm{a}} \\
0.8^{\mathrm{ab}} \\
0.6^{\mathrm{b}}\end{array}$ & $\begin{array}{c}2.7^{\mathrm{a}} \\
2.01^{\mathrm{ab}} \\
1.2^{\mathrm{ab}} \\
0.69^{\mathrm{b}}\end{array}$ & $\begin{array}{l}2.1^{\mathrm{a}} \\
1.4^{\mathrm{a}} \\
0.2^{\mathrm{b}} \\
0.15^{\mathrm{b}}\end{array}$ & $\begin{array}{l}2.3^{\mathrm{a}} \\
1.6^{\mathrm{a}} \\
0.5^{\mathrm{b}}\end{array}$ & $\begin{array}{l}3.4^{\mathrm{a}} \\
2.2^{\mathrm{a}} \\
0.90^{\mathrm{b}} \\
0.41^{\mathrm{b}}\end{array}$ \\
\hline
\end{tabular}

Means within columns followed by the same letter are not significantly different at 5\% probability level in Tukey HSD test. 
interaction between cover crop and herbicide was observed in $B$. tomentellus treatment in 2016 and the lowest percentage of reduction was observed in $A$. desertorum treatment, obtained by $70 \%$ and $25 \%$, respectively, at $600 \mathrm{~g}$ a.i. ha ${ }^{-1}$ concentration. No significant difference was found between the concentrations of 450 and $600 \mathrm{~g}$ a.i. ha ${ }^{-1}$ in all treatments (Table 9).

The interaction between cover crop and herbicide concentrations on Margalof (M) species richness was significant in the rest of the treatments in 2016 except for A. desertorum and had the highest effect on the reduction of species richness in $B$. tomentellus treatment, obtained by $66 \%$ at a concentration of $600 \mathrm{~g}$ a.i. ha ${ }^{-1}$, which was not significantly different with the concentration of 450 g a.i. ha ${ }^{-1}$. In 2017, the interaction between cover crop and herbicide concentration was significant except for $A$. desertorum and $B$. tomentellus treatments. In all treatments, Margalof index (M) reduced with the increase in the herbicide concentration. The highest reduction in Margalof species richness was observed in F. ovina treatment at the concentration of $600 \mathrm{~g}$ a.i. ha ${ }^{-1}$, obtained by $75 \%$. The comparison of mean values indicated a $55 \%$ reduction in species richness caused by B. tomentellus treatment in 2016-17. In both years of experiment, the effect caused by the concentration of $450 \mathrm{~g}$ a.i. ha $\mathrm{h}^{-1}$ had no significant difference with the concentration of $600 \mathrm{~g}$ a.i. ha $\mathrm{h}^{-1}$ in all treatments, except for the control treatment. According to the observations, cover crops were able to change the composition of the weeds in the experimental field. Taraxacum officinale (L.) Weber ex F.H. Wigg, Hyoscyamus niger L., and Tragopogon graminifolius DC. were tested in the second year of the experiment, and some of the species existed in 2016 were not found in the second year (Table 8). In the second year of experiment, all treatments showed an increase in dominance compared to the first year. This means that by reducing diversity, one or more species have found the opportunity to overcome other species. Better establishment of cover species in the second year may be considered as one of the reasons for increasing the dominance.

\section{Discussion}

Weed management is one of the key issues in the development of crop and horticultural crops. Appropriate weed management has the potential to ensure food security by enhancing productivity and increasing profitability of farmers by cutting costs (Yaduraju and Rao, 2013). In the present study, B. tomentellus and F. ovina treatments, had the highest biomass production compared to $F$. rubra and $A$. desertorum. The reduction in dry weight of total broad-leaf weeds influenced by $B$. tomentellus and in both years of the exper-

Table 8. Main weeds recorded in two years of experiment.

\begin{tabular}{cc}
\hline Scientific name & 2016 \\
\hline Polygonum aviculare & Scientific name \\
Descurainia Sophia & Polygonum aviculare \\
\hline Alhagi maurorum & Descurainia Sophia \\
\hline Malva neglecta & Convolvulus arvensis \\
\hline Convolvulus arvensis & Taraxacum officinale \\
\hline Salsola rigida & Alyssum desertorum \\
\hline Sisymbrium Sophia & Hyocyamus niger \\
\hline Gundelia tournefortii & Erodium cicutarium \\
\hline Alyssum desertorum & Planttago lancoelata \\
\hline Veronica persica & Alhagim aurorum \\
\hline Bassia scoparia & Convolvulus arvensis \\
\hline Centaurea dealbata & Tragopogon graminifolius \\
\hline Adonis vernalis & Cardaria draba \\
\hline Sonchus arvensis & \\
\hline Goldbachia laevigata & \\
\hline Cardaria draba & \\
\hline
\end{tabular}

Table 9. Interaction between cover crop and herbicide levels on ecological indicators.

\begin{tabular}{|c|c|c|c|c|}
\hline \multirow[t]{2}{*}{ Cover crop xherbicide (g a.i/ha) } & \multicolumn{2}{|c|}{2016} & \multicolumn{2}{|c|}{2017} \\
\hline & $\mathrm{H}^{\prime}$ & Margalof & $\mathbf{H}^{\prime}$ & Margalof \\
\hline A. desertorum $\times 0$ & $1.6^{\mathrm{a}}$ & $1.4^{\mathrm{a}}$ & $1.7^{\mathrm{a}}$ & $1.9^{\mathrm{a}}$ \\
\hline A. desertorum $\times 300$ & $1.4^{\mathrm{ab}}$ & $1.3^{\mathrm{a}}$ & $1.5^{\mathrm{ab}}$ & $1.8^{\mathrm{a}}$ \\
\hline A. desertorum $\times 450$ & $1.3^{\mathrm{b}}$ & $1.3^{\mathrm{a}}$ & $1.2^{\mathrm{ab}}$ & $1.4^{\mathrm{a}}$ \\
\hline A. desertorum $\times 600$ & $1.2^{\mathrm{d}}$ & $1.2^{\mathrm{a}}$ & $.9^{\mathrm{b}}$ & $0.9^{\mathrm{a}}$ \\
\hline B. tomentellus $\times 0$ & $1^{\mathrm{a}}$ & $0.9^{a}$ & $1^{\mathrm{a}}$ & $1.2^{\mathrm{a}}$ \\
\hline B. tomentellus $\times 300$ & $1^{\mathrm{a}}$ & $0.9^{\mathrm{a}}$ & $0.9^{b}$ & $1^{\mathrm{a}}$ \\
\hline B. tomentellus $\times 450$ & $0.5^{\mathrm{ab}}$ & $0.5^{\mathrm{ab}}$ & $0^{c}$ & $0.7^{\mathrm{a}}$ \\
\hline B. tomentellus $\times 600$ & $0.3^{b}$ & $0.3^{\mathrm{b}}$ & $0^{c}$ & $0.4^{\mathrm{a}}$ \\
\hline F. ovina $\times 0$ & $1.3^{\mathrm{a}}$ & $1.3^{\mathrm{a}}$ & $1.6^{\mathrm{a}}$ & $2^{\mathrm{a}}$ \\
\hline F. ovina $\times 300$ & $1.2^{\mathrm{a}}$ & $1.1^{\mathrm{a}}$ & $1^{a b}$ & $1.2^{\mathrm{ab}}$ \\
\hline F. ovina $\times 450$ & $0.7^{\mathrm{b}}$ & $0.5^{\mathrm{b}}$ & $0.4^{\mathrm{b}}$ & $0.9^{\mathrm{b}}$ \\
\hline F. ovina $\times 600$ & $0.6^{\mathrm{b}}$ & $0.5^{b}$ & $0.3^{b}$ & $0.5^{\mathrm{b}}$ \\
\hline F. rubra $\times 0$ & $1.5^{\mathrm{a}}$ & $1.4^{\mathrm{a}}$ & $1.5^{\mathrm{a}}$ & $1.8^{\mathrm{a}}$ \\
\hline F. rubra $\times 300$ & $1.3^{\mathrm{ab}}$ & $1.1^{\mathrm{ab}}$ & $1.4^{\mathrm{ab}}$ & $1.7^{\mathrm{ab}}$ \\
\hline F. rubra $\times 450$ & $1.2^{\mathrm{bc}}$ & $1^{b}$ & $1.2^{\mathrm{ab}}$ & $1.3^{\mathrm{bc}}$ \\
\hline F. rubra $\times 600$ & $1^{c}$ & $0.9^{b}$ & $1^{b}$ & $1.1 \mathrm{c}$ \\
\hline Control $\times 0$ & $1.8^{\mathrm{a}}$ & $1.9^{\mathrm{a}}$ & $1.6^{\mathrm{a}}$ & $1.9^{\mathrm{a}}$ \\
\hline Control $\times 300$ & $1.6^{\mathrm{a}}$ & $1.6^{\mathrm{a}}$ & $1.5^{b}$ & $1.6^{\mathrm{a}}$ \\
\hline Control $\times 450$ & $1.5^{\mathrm{ab}}$ & $1.4^{\mathrm{a}}$ & $1.4^{c}$ & $1.4^{\mathrm{a}}$ \\
\hline Control $\times 600$ & $1^{\mathrm{b}}$ & $0.8^{b}$ & $1.2^{\mathrm{d}}$ & $0.8^{b}$ \\
\hline
\end{tabular}

Means within columns followed by the same letter are not significantly different at $5 \%$ probability level in Tukey HSD test. 
iment was found to be more than other cover crops. is more drought-tolerant and can provide a more naturalised look (Pessarakli, 2007). Weed suppression by cover crops can be due to resource competition, niche disruption, and phytotoxic effects and it can be directly proportional to cover crop growth and canopy production (Liebman and Davis, 2000). Tabatabaifar (2012) reported that planting winter cover crops has a beneficial effect on controlling and suppressing the weed.

B. tomentellus treatment had $55 \%$ and $78 \%$, treatment had $41 \%$ and $71 \%$, of dry weight of total weeds compared to control in 2016 and 2016-17, respectively before application of herbicide. But after the application of herbicides, in 2016, the highest reduction in dry weight of broad-leaf weeds at the concentration of $600 \mathrm{~g}$ a.i. $\mathrm{ha}^{-1}$ was observed in $F$. ovina (94\%) and in 2016, reduction of weed dry weight was influenced by the interaction between cover crop and herbicide concentrations in B. tomentellus (90\%). In a study by (Bangarwa et al., 2009), the interactive effect of using Caliente mustard along with herbicide was found to be effective on weed control and enhancement of Capsicum annuum yield. Most of the previous studies typically reported the effectiveness of cover crops in suppression of weeds in terms of qualitative characteristics (Linares et al., 2008). In both years of experiment, the interactive effect between herbicide concentration and cover crop on total dominant weed (P. aviculare, A. desertorum, D. Sophia) weights was found to be significant in all treatments. B. tomentellus and were able to reduce of dry weight dominant weeds in both years of experiment. Even with the use of cultural practice, prevalent weed pressure often requires the management using herbicides (Koger et al., 2002). Seemingly, the success of F. ovina at the site is related to the ability of the species to tolerate moisture stress under conditions in which its growth is severely restricted by mineral nutrient stress (Grime and Curtis, 1976). B. tomentellus could take part in the light competition due to the early germination (Rezvannejad and Sharafi, 2016). Current cropping practices such as using smother crops and narrow row spacing exploit plant light responses to promote crop growth and suppress weed growth (Holt, 1995).

In 2016 and 2017, based on Shannon Wiener $\left(H^{\prime}\right)$ index, the interaction between cover crop and herbicide concentration of Bromocide M.A. EC was significant in all treatments. By increasing the concentration of herbicide, the index reduced in all treatments. The interaction between cover crop and herbicide concentrations showed that $B$. tomentellus and $F$. ovina were able to alert the ecological index Shannon Wiener and Margalof in both years of experiment. Bybee-Finley et al., (2017) found several negative relationships between crop species richness and weed biomass and crop biomass was found to be a more important factor than species richness for suppression of weeds. Phophi et al. (2017) reported that, lablab and velvet bean (cover crop) had significantly lower weed species diversity at week 16 compared to the rest of the treatments, and also they found that, herbicide causes high weed species diversity. In this experiment it was observed that some species change under the influence of cover crop plants. Cover crop and crop management system can influence weed populations and yield in the short and long term (Ngouajio et al., 2003). The diversity indices are generally concurred with the trends in species richness. Particularly, the Shannon diversity index, which is biased toward species richness (Magurran, 1988). Although, cover crops reduced species richness, they increased Simpson's diversity. This increase was due to the increased equitability, when weed density reduced (Clements et al., 1994).

\section{Conclusions}

The findings of the present study can be applied for controlling lands' weeds at fallow, pre-plantation of the main crop or orchard as cover crop. The results showed that, the dry weight of broad-leaf weeds was influenced by $B$. tomentellus and $F$. ovina treatments in both years of experiment and the use of Bromocide M.A. EC herbicide once a year along with cover crops was found to be effective to provide conditions for better establishment of cover crops, by influencing broad-leaf weeds using herbicide at concentrations of 450 and $600 \mathrm{~g}$ a.i. ha ${ }^{-1}$. In both years of experiment, Shannon Wiener $\left(H^{\prime}\right)$ index reduced in all treatments with the increase in the herbicide concentration. In general, it is recommended to use these two types of cover crops for weed management in order to achieve sustainable agriculture. In future studies, it is recommended to study the economic aspects of these plants for use in orchard.

\section{Highlights}

- Bromus tomentellus Bioss and Festuca ovina L had the highest biomass production.

- Bromus tomentellus (90\%) and Festuca ovina (73\%) treatments had the highest decrease in total weed dry weight compared to control.

- The highest reduction in dry weight of total dominant weeds was influenced by B. tomentellus and Festuca ovina $73 \%$ and $83 \%$ at the rate of $600 \mathrm{~g}$ a.i. $\mathrm{ha}^{-1}$ of Bromocide M.A. EC respectively.

- Margalof index reduced following the increase in herbicide concentration in all treatments.

Bromus tomentellus, Festuca ovina has the potential for reducing weeds in orchards and croplands.

\section{References}

Armaki MA, Hashemi M, Azarniv H, 2013. Physiological and morphological responses of three Bromus species to drought stress at seedling stage and grown under germinator and greenhouse conditions. AJPS. 7:155-61.

Bangarwa SK, Norsworthy JK, Gbur EE, 2009. Cover crop and herbicide combinations for weed control in polyethylenemulched bell pepper. HortTechn. 19:405-10.

Bàrberi P, Mazzoncini M, 2001. Changes in weed community composition as influenced by cover crop and management system in continuous corn. Weed Sci. 49:491-9.

Booth BD, Murphy SD, Swanton CJ, 2003. Weed ecology in natural and agricultural systems. CABI Publishing.

Bybee-Finley KA, Mirsky SB, Ryan MR, 2017. Crop biomass not species richness drives weed suppression in warm-season annual grass-legume intercrops in the Northeast. Weed Sci. 65:669-80.

Cléments DR, Weise SF, Swanton CJ, 1994. Integrated weed management and weed species diversity. Phytoprot. 75:1-18.

Fernandez C, Monnier Y, Santonja M, Gallet C, Weston LA, Prévosto B, Bousquet-Mélou A, 2016. The impact of competition and allelopathy on the trade-off between plant defense and growth in two contrasting tree species. Front. Plant Sci. 7:594.

Fourie JC, Louw PJE, Agenbag GA, 2001. Effect of seeding date on the performance of grasses and broadleaf species evaluated for cover crop management in two wine grape regions of South 
Africa. SAJPS.18:118-27.

Grime JP, Curtis AV, 1976. The interaction of drought and mineral nutrient stress in calcareous grassland. J. Ecol. 975-88.

Håkansson S, 2003. Weeds and weed management on arable land: an ecological approach. CABI Publishing.

Hein T, 2014. Herbicide impacts on establishing cover crops. Available from: https://www.topcropmanager.com/tillage/herbicide-impacts-on-establishing-cover-crops 16150

Hock SM, Knezevic SZ, Martin AR, Lindquist JL, 2006. Soybean row spacing and weed emergence time influence weed competitiveness and competitive indices. Weed Sci. 54:38-46.

Holt J, 1995. Plant responses to light: a potential tool for weed management. Weed Sci. 43:474-82.

Jabran K, Mahajan G, Sardana V, Chauhan BS, 2015. Allelopathy for weed control in agricultural systems. J. Crop Prot. 72:5765.

Koger CH, Reddy KN, Shaw DR, 2002. Effects of rye cover crop residue and herbicides on weed control in narrow and wide row soybean planting systems. Weed Biol. Manage. 2:216-24.

Liebman M, Davis AS, 2000. Integration of soil, crop and weed management in low-external-input farming systems. Weed Res.-Oxford. 40:27-48.

Linares J, Scholberg JMS, Chase C, McSorley R, 2008. Evaluation of annual warm-season cover crops for weed management in organic citrus. pp 235-242 in Organic Fruit Conference 873.

Magurran AE, 1988. Ecological diversity and its measurement. Princeton University Press.

Mitrović M, Pavlović P, Lakušić D, Djurdjević L, Stevanović B, Kostić O, Gajić G, 2008. The potential of Festuca rubra and Calamagrostis epigejos for the revegetation of fly ash deposits. Sci. Total Environ. 407:338-47.

Ngouajio M, McGiffen JrME, Hutchinson CM, 2003. Effect of cover crop and management system on weed populations in lettuce. J. Crop Prot. 22:57-64.

Pessarakli M, 2007. Handbook of turfgrass management and physiology. CRC Press, Boca Raton, FL, USA.

Phophi MM, Mafongoya PL, Odindo AO, Magwaza LS, 2017. Screening cover crops for weed suppression in conservation agriculture. Sustain. Agric. Res. 6:526-2017-2700.

Reddy KN, 2003. Impact of rye cover crop and herbicides on weeds, yield, and net return in narrow-row transgenic and con- ventional soybean (Glycine max). Weed Technol. 17:28-35.

Rezvannejad E, Sharafi M, 2016. Evaluation of competitive ability in Artemisia (Artemisia aucheri) with Bromus (Bromus tomentellus) and relationship with the amount and distribution of leaf canopy. EASL. 3:30-7.

Rognli OA, Saha MC, Bhamidimarri S, van der Heijden S, 2010. Fescues. In: Fodder Crops and Amenity Grasses. Springer, New York, NY, pp. 261-292.

Saeedi Goraghani HR, Heidary GA, Solaimani Sardo M, 2013. Effects of salinity and drought stresses on seed germination and seedling growth of desert wheatgrass Agropyron desertorum. JRS. 4:14-22.

San Emeterio L, Damgaard C, Canals RM, 2007. Modelling the combined effect of chemical interference and resource competition on the individual growth of two herbaceous populations. Plant Soil 292:95-103.

Sikoriya S, 2014. Phenological study and management of red fescue (Festuca rubra) in wild blueberry. Dalhousie University Halifax, Nova Scotia.

Tabatabaifar SAT, 2012. The effect of barley grass cover crop on control weed of flix weld (Descurainia Sophia) J. Exp. Biol. 2:2257-63.

Teasdale JR, Pillai P, Collins RT, 2005. Synergism between cover crop residue and herbicide activity on emergence and early growth of weeds. Weed Sci. 53:521-7.

Tribouillois H, Fort F, Cruz P, Charles R, Flores O, Garnier E, Justes E, 2015. A functional characterisation of a wide range of cover crop species: growth and nitrogen acquisition rates, leaf traits and ecological strategies. PLoS One 10:e0122156.

Westbrook J, Carr C, Hatfield P, Miller P, Menalled F, 2015. Sheep grazing for field pea cover crop termination in a winter wheat production system. College of Agriculture and Extension, P.61.

Yaduraju NT, Rao AN, 2013. Implications of weeds and weed management on food security and safety in the Asia-Pacific region. pp 13-30 in The role of weed science in supporting food security by 2020 . Proceedings of the 24th Asian-Pacific Weed Science Society Conference, October 22-25, Bandung, Indonesia. 